\title{
Correction to: Satirical contribution: COVID-19 research updates: does wearing tinfoil hats pose neurodegenerative threats to conspiracists and the general public?
}

\author{
I. M. Portant ${ }^{1} \cdot$ R. E. Sults ${ }^{1}$
}

Published online: 11 May 2021

๑) Springer-Verlag GmbH Germany, part of Springer Nature 2021

\section{Correction to: Archives of Toxicology \\ https://doi.org/10.1007/s00204-021-03051-x}

In this contribution, an incorrect e-mail address of I.M. Portant was listed.

Correct is: i.m.portant@gmx.de.

Publisher's Note Springer Nature remains neutral with regard to jurisdictional claims in published maps and institutional affiliations.

The original article can be found online at https://doi.org/10.1007/ s00204-021-03051-x.

I. M. Portant

i.m.portant@gmx.de

1 Awkward Medical School/Moron Institute of Technology,

Dortmund, Germany 